УдК 343.146

\author{
C. О. Ковальчук
}

\title{
ЄВРОПЕЙСЬКІ ПРАВОВІ СТАНДАРТИ ФОРМУВАННЯ В ХОДІ КРИМІНАЛЬНОГО ПРОВАДЖЕННЯ ДОПУСТИМИХ РЕЧОВИХ ДОКАЗІВ
}

Постановка проблеми. Гармонізація законодавства України з правом Європейського Союзу зумовлює необхідність подальшого реформування всіх сфер суспільного життя. Зокрема, Стратегія сталого розвитку «Україна - 2020», схвалена Указом Президента України від 12 січня 2015 р. № 5/2015, передбачає реалізацію 62 реформ і програм розвитку держави, у тому числі й судової реформи, яка має на меті реформування судоустрою, судочинства та суміжних правових інститутів задля практичної реалізації принципів верховенства права й забезпечення кожному права на справедливий судовий розгляд справ незалежним і неупередженим судом, а також повинна забезпечити функціонування судової влади, що відповідає суспільним очікуванням щодо незалежного й справедливого суду, європейській системі цінностей і стандартів захисту прав людини [1]. Пріоритетність забезпечення європейських цінностей і стандартів захисту прав людини в процесі функціонування судової влади визнається як складова частина мети Стратегії реформування судоустрою, судочинства та суміжних правових інститутів на 2015-2020 рр., схваленої Указом Президента України від 20 травня 2015 р. № 276/2015 [2].

Вагома роль у забезпеченні захисту прав людини належить Європейському суду з прав людини (далі - ЄСПЛ), практика якого, відповідно до ст. 17 Закону України «Про виконання рішень та застосування практики Європейського суду з прав людини» від 23 лютого 2006 р. № 3477-IV, підлягає застосуванню судами як джерело права [3]. Здійснюючи захист прав людини, ЄСПЛ сформував значну кількість європейських правових стандартів доказування та допустимості доказів, які підлягають застосуванню в кримінальному провадженні.

Аналіз останніх досліджень і публікацій. Вивченню правових позицій ЄСПЛ у частині доказування в кримінальному провадженні присвячено праці А.В. Деменевої, Т.Г. Морщакової, В.Т. Нора, П.М. Рабіновича, 
Б.П. Ратушної, В.В. Тютюнника, С.В. Шевчука та інших вітчизняних $і$ зарубіжних учених. Зокрема, В.Т. Нором досліджено застосування в практиці ЄСПЛ презумпції невинуватості як конституційної засади кримінального судочинства [4], П.М. Рабіновичем і Б.П. Ратушною - європейські стандарти належного доказування в кримінальному судочинстві та стан їх дотримання в Україні [5], а В.В. Тютюнником - вПлив практики ЄСПЛ на розвиток інституту допустимості доказів у кримінальному процесі України [6]. Водночас самостійні дослідження напрацьованих ЄСПЛ правових стандартів, пов'язаних із формуванням допустимих речових доказів, не проводились.

Метою статті $є$ аналіз європейських правових стандартів формування в ході кримінального провадження допустимих речових доказів.

Виклад основного матеріалу. У низці рішень ЄСПЛ застосовує до оцінки дотримання національними судами процедури формування доказів, у тому числі й речових, традиційний підхід, за якого питання про їх допустимість досліджується в контексті справедливості судового розгляду в цілому. Так, у справі «Шенк проти Швейцарії ЄСПЛ вказав, що згідно зі ст. 19 Конвенції про захист прав людини й основоположних свобод від 4 листопада 1950 р. (далі - Конвенція) завдання ЄСПЛ полягає в забезпеченні дотримання зобов'язань, прийнятих на себе договірними державами за Конвенцією. Він не покликаний досліджувати фактичні й правові помилки, нібито допущені національними судами, якщо лише вони тією чи іншою мірою не ведуть до порушення прав і свобод, охоронюваних Конвенцією. Стаття 6 Конвенції гарантує право на справедливий судовий розгляд, проте не встановлює будь-яких правил допустимості доказів як таких, оскільки це є завданням внутрішнього права. ЄСПЛ, таким чином, не може виключити принципово та in abstracto прийнятність таких незаконно отриманих доказів. Він повинен лише оцінити, чи був судовий розгляд у цілому справедливим (п. п. 45 і 46 Рішення ЄСПЛ у справі «Шенк проти Швейцарії» від 12 липня 1988 р.) [7].

У подальшому ЄСПЛ дещо уточнив наведену позицію як щодо оцінки доказів національними судами, так і щодо здійснюваної ЄСПЛ оцінки справедливості судового розгляду в цілому. Зокрема, у справі «Бербера, Мессеге і Хабардо проти Іспанії ЄСПЛ відзначив, що, як правило, національні суди, зокрема суд першої інстанції, повинні оцінити подані їм докази, а ЄСПЛ має визначити, чи може судовий розгляд, у тому числі способи, за допомогою яких обвинувачення й захист отримали докази, вважатися справедливим, як того вимагає ст. 6-1 Конвенції (п. 68 Рішення ЄСПЛ у справі «Бербера, Мессеге і Хабардо проти Іспанії від 6 грудня 1988 р.) [8].

Широко використовуючи наведені правові позиції (у повному обсязі або частково) для обгрунтування допущених національними судами порушень Конвенції в низці інших справ, ЄСПЛ у своїй практиці протягом тривалого часу продовжував розглядати законність способів формування доказів у контексті справедливості судового розгляду в цілому, прямо вказуючи на відсутність у нього обов'язку оцінювати допустимість доказів. Зокрема, у 
справі «Хан проти Сполученого Королівства» ЄСПЛ вказав, що вирішення ним питання про те, чи є судовий розгляд, у тому числі й способи отримання доказів, справедливим, включає в себе вивчення «незаконності» та в разі порушення іншого права, гарантованого Конвенцією, характеру порушення (п. 34 Рішення ЄСПЛ у справі «Хан проти Сполученого Королівства» від 12 травня 2000 р.) [9]. У п. 52 Рішення ЄСПЛ у справі «Раманаускас проти Литви» від 5 лютого 2008 р. ЄСПЛ зазначив, що він зобов'язаний не з'ясовувати, чи було отримано певні докази незаконно, а перевіряти, чи така «незаконність» не спричинила порушення іншого права, гарантованого Конвенцією [10].

Із часом ЄСПЛ почав поступово відходити від застосування традиційного підходу, вказавши в п. 90 Постанови ЄСПЛ за справою «Биков проти Російської Федерації» від 10 березня 2009 р. та в п. 49 Рішення ЄСПЛ «Лісіка проти Хорватії» від 25 лютого 2010 р., що необхідно враховувати якість доказів, з'ясовувати, чи могли обставини, за яких їх було отримано, поставити під сумнів ї достовірність або точність $[11 ; 12]$. Водночас ЄСПЛ, досліджуючи способи формування доказів, у тому числі й речових, використовує статичний підхід, за допомогою якого, як правило, встановлює порушення фундаментальних вимог Конвенції, наслідком яких виступає неможливість використання цих доказів у кримінальному провадженні. При цьому, як обгрунтовано вказується в загальній особливій думці суддів у Рішенні ЄСПЛ у справі «Шенк проти Швейцарії, дотримання закону під час отримання доказів не є абстрактною або суто формальною вимогою. Навпаки, це має першорядне значення для справедливості судового розгляду в кримінальних справах. Жоден суд не може, не завдаючи шкоди належному відправленню правосуддя, спиратися на доказ, який було отримано не просто нечесним шляхом, а насамперед протизаконно. Якщо суд так вчиняє, він не може вважатися справедливим у розумінні Конвенції (Рішення ЄСПЛ у справі «Шенк проти Швейцарії від 12 липня 1988 p.) [7].

Предметом оцінки ЄСПЛ доказу з позиції «законності» способу його отримання, як відзначає В.В. Тютюнник, є закріплені в законі підстави та порядок проведення процесуальної дії, спрямованої на отримання доказу, а також комплекс інших допоміжних заходів, що здійснюються в межах процедури проведення процесуальної дії. Критерієм такої оцінки $є$ відповідність складових, що утворюють «механізм отримання доказів», правам i свободам, які охороняються Конвенцією [6, с. 86-87]. Так, у частині оцінки законності способів отримання речових доказів ЄСПЛ визначає належність використовуваних для їх збирання процесуальних дій, дотримання порядку їх проведення та достатність цих дій для формування необхідних речових доказів.

Оцінку належності процесуальних дій, використовуваних для збирання речових доказів, надано ЄСПЛ у справах «Функе проти Франції, «Бук проти Німеччини», «Смірнов проти Росії, «Лісіка проти Хорватії» тощо. Зокрема, у п. 56 Рішення ЄСПЛ у справі «Функе проти Франції» від 25 
лютого 1993 р. суд визнає, що держави мають право вдатися до деяких заходів, наприклад огляду житла та вилучення, для встановлення речових доказів вчинення правопорушень [13]. У п. 52 Рішення ЄСПЛ у справі «Бук проти Німеччини» від 28 квітня 2005 р. суд наголосив, що держави, вживаючи заходів щодо запобігання заворушенням або вчиненню злочинів, щоб захистити права інших осіб, за необхідності можуть проводити обшук і виїмку з метою отримання доказів на підтвердження вчинення певних видів злочинів, якщо іншим способом встановити особу винного неможливо [14]. У п. 44 Постанови ЄСПЛ у справі «Смірнов проти Росії» від 7 червня 2007 р. ЄСПЛ щодо провадження обшуків приміщень і вилучень вказав: «Високі Договірні Сторони Конвенції мають право визнати за необхідне вдаватися до таких заходів для отримання речових доказів вчинення певних злочинів» [15]. У п. 56 Рішення ЄСПЛ у справі «Лісіка проти Хорватії» від 25 лютого 2010 р. суд відзначив, що проведення декількох обшуків того ж приміщення в жодному разі не суперечить принципам справедливого судового розгляду [11].

На необхідність дотримання порядку проведення процесуальних дій, спрямованих на збирання речових доказів, ЄСПЛ звернув увагу в справах «Імакаєва проти Росії, «Смірнов проти Росії, «Андре та інші проти Франції, «Головань проти України» тощо. Так, у п. п. 187-189 Постанови ЄСПЛ у справі «Імакаєва проти Росії» від 9 листопада 2006 р. ЄСПЛ 3 огляду на непред’явлення заявниці під час обшуку ордеру на обшук і ненадання їй інформації про те, що шукали, неможливість надання урядом подробиць щодо причин обшуку, посилань на його законність або позначення процесуальної значимості таких дій та неможливість надання інформації про те, які речі було вилучено в будинку Імакаєвих (оскільки їх нібито було знищено), визнав, що обшук і вилучення в цій справі було проведено без санкції або належних гарантій [16]. У п. п. 45 і 48 Постанови ЄСПЛ у справі «Смірнов проти Росії від 7 червня 2007 р. суд зауважив, що надмірно широкі вислови, у яких було сформульовано постанову про проведення обшуку, надали співробітникам міліції необмежений розсуд під час визначення, які документи «представляли інтерес» для розслідування в кримінальній справі. У результаті було проведено поширений обшук і потім вилучення. До вилучених матеріалів належали не лише ті, що мали відношення до підприємницької діяльності двох приватних компаній, співробітники міліції забрали також особисту записну книжку заявника, центральний блок його комп’ютера й інші матеріали, у тому числі довіреність від імені його довірителя на ведення цивільної справи, не пов’язаної із цією кримінальною справою, та чернетку процесуальної записки в іншій справі [15].

У п. 45 Постанови ЄСПЛ у справі «Андре та інші проти Франції» від 24 липня 2008 р. суд відзначив, що дозвіл на огляд житла було сформульовано в загальних висловах, постанову обмежено тим, що було наказано провести огляди й виїмки, необхідні для збирання доказів вчинення злочинних дій в окремих місцях, де могли знаходитись документи та носії 
інформації, що мають відношення до передбачуваного шахрайства, зокрема, за робочою адресою заявників. У зв'язку із цим посадовим особам і співробітникам судової поліції надавалися широкі повноваження [17]. У п. 61 Рішення ЄСПЛ у справі «Головань проти України» від 5 липня 2012 р. ЄСПЛ вказав, що стандарт передбачуваності було підірвано необгрунтованими гарантіями в національному законодавстві щодо того, що ордери на обшук повинні засновуватись на належних підозрах та оформлюватись з обгрунтованою точністю й подробицями. Сумісність ордеру на обшук із цими вимогами завжди була предметом турботи для ЄСПЛ. Унаслідок цього ордер на обшук не вказував та не обгрунтовував підстави, які привели слідчого до висновку, що в офісі першого заявника могли бути знайдені докази [18].

При цьому ЄСПЛ звертає увагу на необхідність забезпечення під час проведення процесуальних дій, у ході яких вилучаються речові докази, відповідних гарантій. Такими гарантіями з огляду на практику ЄСПЛ виступають як достатні гарантії для захисту від зловживань (п. 56 Рішення ЄСПЛ у справі «Функе проти Франції» від 25 лютого 1993 р. [13]), у тому числі Й адекватні та ефективні заходи захисту від зловживань владою (п. 31 Рішення ЄСПЛ у справі «Кіган проти Сполученого Королівства» від 18 липня 2006 р. [19]), так і гарантії забезпечення охоронюваних законом таємниць, зокрема й адвокатської (п. 48 Постанови ЄСПЛ у справі «Смірнов проти Росії» від 7 червня 2007 р. [15], п. 62 Рішення ЄСПЛ у справі «Головань проти України» від 5 липня 2012 р. [18]). У п. 56 Рішення ЄСПЛ у справі «Лісіка проти Хорватії» від 25 лютого 2010 р. суд вказав, що кожен обшук повинен відповідати мінімальним вимогам, щоб обвинувачений у кримінальному судочинстві мав адекватну можливість бути присутнім під час обшуку [11]. На необхідності забезпечення гарантій прав особи під час отримання доказів шляхом обшуку увага акцентується також у юридичній літературі [20, с. 20].

У низці справ ЄСПЛ, здійснюючи оцінку дотримання порядку проведення процесуальних дій, спрямованих на збирання речових доказів, виходить із забезпечення принципу пропорційності (співмірності) втручання в права громадян із метою, яка підлягає досягненню за допомогою відповідних дій. Оцінку дотриманню принципу пропорційності (співмірності) ЄСПЛ надав у справах «Бук проти Німеччини», «Кіган проти Сполученого Королівства», «Андре та інші проти Франції тощо. Зокрема, у п. 52 Рішення ЄСПЛ у справі «Бук проти Німеччини» від 28 квітня 2005 р. суд визнав непропорційним меті, яку воно переслідувало, втручання, що полягало в наданні дозволу на відповідні обшук і виїмку у зв'язку з незначним правопорушенням, учиненим третьою особою, з його поширенням на приватне житло заявника [14]. У п. п. 33-36 Постанови ЄСПЛ у справі «Кіган проти Сполученого Королівства» від 18 липня 2006 р. ЄСПЛ дійшов висновку про недотримання належним чином балансу та порушення ст. 8 Конвенції внаслідок проведення обшуку в житлі заявників, які проживали за цією адресою близько 6 місяців та не мали жодного стосунку до підозрюваних 
або злочинів, а також про неможливість розгляду як співмірних подальших дій співробітників поліції, які вселили в заявників значний страх і сум'яття [19]. У п. П. 47-48 Постанови ЄСПЛ у справі «Андре та інші проти Франції від 24 липня 2008 р. суд визнав неспівмірними щодо переслідуваної мети огляди житла заявників і виїмки, проведені в межах здійснення податкової перевірки компанії, яка була клієнтом заявників [17].

При цьому в п. 45 Рішення ЄСПЛ у справі «Бук проти Німеччини» від 28 квітня 2005 р. суд розглянув гарантії проти зловживання владою під час проведення обшуків приміщень і вилучення в контексті дотримання принципу пропорційності та визначив дотримання порядку проведення процесуальних дій, спрямованих на збирання речових доказів, як критерію оцінки забезпечення реалізації цього принципу. Зокрема, ЄСПЛ вказав, що він оцінюватиме, чи були належними й достатніми підстави, наведені на обгрунтування проведення обшуку житла й виїмки з нього, і чи було дотримано принцип пропорційності. Щодо останнього ЄСПЛ, по-перше, повинен переконатися, що у відповідному національному законодавстві та на практиці особи забезпечуються належними гарантіями від зловживань. По-друге, суд має розглянути обставини кожної справи, щоб з'ясувати, чи відповідне втручання в конкретній справі було пропорційним цілі, яку воно переслідувало. Критеріями, які ЄСПЛ враховує під час з'ясування цього питання, є тяжкість правопорушення, у зв'язку з яким проводились обшук і виїмка, обставини, за яких ухвалено відповідну постанову (зокрема, наявність інших доказів на той момент), зміст та обсяг постанови, статус приміщення, яке підлягало обшуку, заходи, вжиті з метою розумного обмеження впливу обшуку, і можливі наслідки для репутації особи, у приміщенні якої ці дії здійснювались [14].

У подальшому ЄСПЛ у повному обсязі використав наведені правові позиції в справі «Смірнов проти Росіі», дещо уточнивши при цьому коло критеріїв, якими він керується під час вирішення питання про пропорційність акту втручання держави в здійснення прав людини меті, яку він переслідував. Зокрема, ЄСПЛ до таких критеріїв відніс, серед іншого, обставини, за яких видавався ордер на обшук (зокрема, наявність додаткових доказів на момент видання ордера); зміст і сферу дії ордера на обшук; спосіб провадження обшуку, у тому числі присутність незалежних спостерігачів під час проведення обшуку; масштаби можливих наслідків обшуку, які можуть позначитись на роботі й репутації особи, у якої проводиться обшук (п. 44 Постанови ЄСПЛ у справі «Смірнов проти Росії від 7 червня 2007 р.) [15].

Наведене у вказаних справах коло критеріїв дотримання принципу пропорційності (співмірності) стало наслідком узагальнення напрацьованих ЄСПЛ правових позицій у частині їх визначення як у наведених, так і в інших справах. Такими критеріями визнано тяжкість правопорушення, у зв'язку з яким проводиться обшук, межі дії постанови й наслідки обшуку для репутації обшукуваного (п. п. 47, 50 і 51 Рішення ЄСПЛ у справі «Бук проти Німеччини» від 28 квітня 2005 р. [14]); межі дії постанови про проведення обшуку та присутність незалежних спостерігачів (п. п. 47 i 
48 Постанови ЄСПЛ у справі «Смірнов проти Росії» від 7 червня 2007 р. [15]); наявність незалежних спостерігачів під час проведення обшуку та його наслідки для репутації обшукуваного (п. п. 37 і 38 Рішення ЄСПЛ у справі «Німітц проти Німеччини» від 16 грудня 1992 р. [21]); наявність судового мандату (п. 57 Рішення ЄСПЛ у справі «Функе проти Франції» від 25 лютого 1993 р. [13]); спосіб проведення обшуку (п. 46 Рішення ЄСПЛ у справі «Камензінд проти Швейцарії від 16 грудня 1997 р. [22]) тощо.

У п. 49 Постанови ЄСПЛ у справі «Смірнов проти Росії» від 7 червня 2007 р. суд використовує, крім принципу пропорційності (співмірності) втручання в права громадян передбачуваній меті, критерій його необхідності. Зокрема, ЄСПЛ відзначає, що обшук, проведений без важливих i достатніх підстав та за відсутності гарантій проти порушення адвокатської таємниці в квартирі заявника, який не обвинувачувався у вчиненні будь-якого злочину, проте представляв інтереси обвинувачених у тій самій кримінальній справі, не був «необхідним у демократичному суспільстві» [15]. Поняття «необхідність» визначається в п. 61 Рішення ЄСПЛ у справі «Олссон проти Швеції» від 24 березня 1988 р., у якому ЄСПЛ вказав, що відповідно до сформованої ним практики поняття необхідності має на увазі, що втручання відповідає якій-небудь нагальній потребі та виступає пропорційним переслідуваній законній меті [23].

У зв'язку із цим у п. 61 Рішення ЄСПЛ у справі «Олссон проти Швеції» від 2 березня 1988 р. [23], у п. 55 Рішення ЄСПЛ у справі «Функе проти Франції» від 25 лютого 1993 р. [13], у п. 44 Рішення ЄСПЛ у справі «Бук проти Німеччини» від 28 квітня 2005 р. [14] та інших справах ЄСПЛ стверджує, що під час визначення того, чи є втручання «необхідним у демократичному суспільстві», він враховує, що за державами-учасницями Конвенції залишається певна свобода розсуду. Водночас у п. 55 Рішення ЄСПЛ у справі «Функе проти Франції» від 25 лютого 1993 р. [13], у п. 44 Рішення ЄСПЛ у справі «Бук проти Німеччини» від 28 квітня 2005 р. [14], у п. 31 Рішення ЄСПЛ у справі «Кіган проти Сполученого Королівства» від 18 липня 2006 р. [19] та інших справах ЄСПЛ вказує на існування винятків (меж розсуду), визначених п. 2 ст. 8 Конвенції, однак наголошує, що вони мають вузько тлумачитись, а необхідність у їх застосуванні має бути переконливо встановленою.

У більшості справ ЄСПЛ надає ситуативну оцінку дотриманню порядку проведення процесуальних дій, вказуючи на незаконність отримання речових доказів з огляду на обставини конкретної справи та напрацьовану ним практику. Водночас в окремих справах ЄСПЛ однозначно вказує на недопустимість речових доказів і неможливість їх використання, що має місце в таких випадках: 1) отримання речових доказів унаслідок застосування актів насильства, жорстокості або інших форм поводження, які можна характеризувати як тортури, а також погроз іх застосування; 2) отримання речових доказів за обставин, які свідчать про їх явну недопустимість.

На недопустимість речових доказів, отриманих із застосуванням актів насильства, жорстокості чи інших форм поводження, які можна харак- 
теризувати як тортури, ЄСПЛ вказав у п. 105 Рішення ЄСПЛ у справі «Яллох проти Німеччини» від 11 липня 2006 р. Зокрема, суд відзначив, що викриваючий доказ (у формі визнання або речового доказу), отриманий у результаті актів насильства чи жорстокості або інших форм поводження, що може характеризуватись як тортури, ніколи не повинен розглядатись як доказ винуватості жертви незалежно від його доказового значення [24].

У подальшому ЄСПЛ використовував наведену правову позицію в справах «Харутунян проти Вірменіі», «Гефген проти Німеччини» тощо, уточнюючи з огляду на обставини справи підхід до визначення дій, які охоплюються поняттям тортур. Зокрема, у п. 63 Постанови ЄСПЛ у справі «Харутюнян проти Вірменії від 28 червня 2007 р. суд уточнив, що такий доказ не може бути отримано в результаті насильницьких дій або застосування жорстокості чи інших форм поводження, які можна характеризувати як тортури [25]. У Постанові ЄСПЛ у справі «Гефген проти Німеччини» від 30 червня 2008 р. суд вказав: «Заявник <..> піддався досить реальній і безпосередній загрозі умисного жорстокого поводження. <...> Поводження із заявником мало заподіяти йому значні моральні страждання, і погрози в разі їх приведення у виконання являли б собою тортури». ЄСПЛ вважає, що поводження, якому піддався заявник під час допиту, було нелюдським [26].

Напрацьована практика дозволила ЄСПЛ сформувати загальний підхід до визначення дій, які охоплюються поняттям тортур. Так, у п. п. 49 і $50 \mathrm{Pi}$ шення ЄСПЛ у справі «Алексахін проти України» від 19 липня 2012 р. [27] суд вказав, що під час визначення того, чи має певна форма жорстокого поводження кваліфікуватись як катування, варто брати до уваги розрізнення, що міститься в ст. 3 Конвенції, між цим поняттям і нелюдським або таким, що принижує людську гідність, поводженням. Окрім жорстокості поводження, ознакою катування є також наявність мети такого поводження, як це встановлено в Конвенції ООН проти катувань та інших жорстоких, нелюдських або таких, що принижують гідність, видів поводження та покарання.

При цьому в п. 105 Рішення ЄСПЛ у справі «Яллох проти Німеччини» від 11 липня 2006 р. [24], у п. 74 Постанови ЄСПЛ у справі «Гечмен проти Туреччини» від 17 жовтня 2006 р. [28], у п. 63 Постанови ЄСПЛ у справі «Харутюнян проти Вірменіі» від 28 червня 2007 р. [25], у п. 100 Постанови ЄСПЛ у справі «Левінца проти Молдови» від 16 грудня 2008 р. [29] та інших справах ЄСПЛ послідовно відстоює позицію про те, що докази, у тому числі й речові, отримані із застосуванням актів насильства, жорстокості або інших форм поводження, які можна характеризувати як тортури, не можуть використовуватись незалежно від їх впливу на доказову базу. У юридичній літературі наголошується, що за критерієм справедливості розгляду в цілому ЄСПЛ може оцінювати події заднім числом, коли процес уже завершено та можна зробити висновок про те, як саме використання того чи іншого доказу вплинуло на результат справи [30, с. 41]. Хоча правові позиції ЄСПЛ свідчать про неприпустимість використання доказів, отриманих із застосуванням актів насильства, жорстокості чи інших форм 
поводження, які можна характеризувати як тортури, а також погроз їх застосування, ЄСПЛ визначає вплив того або іншого доказу на результат вирішення справи під час визначення справедливості судового розгляду в цілому. Зокрема, надаючи оцінку речовим доказам, отриманим унаслідок застосування погроз фізичного насильства, ЄСПЛ у Постанові за справою «Гефген проти Німеччини» від 30 червня 2008 р. вказав, що використання доказів не робить судовий розгляд несправедливим автоматично, хоча й створює сильну презумпцію несправедливості [26].

Аналізуючи європейські стандарти належного доказування в кримінальному судочинстві, П.М. Рабінович і Б.П. Ратушна відзначають, що в деяких випадках ЄСПЛ, навпаки, висловлюється проти автоматичного вилучення належних і важливих матеріалів серед доказів у зв'язку з порушеннями, допущеними під час їх отримання, вважаючи їх умовно допустимими [5, с. 57]. Зокрема, у п. 46 Рішення ЄСПЛ у справі «Шенк проти Швейцарії від 12 липня 1988 р. суд звернув увагу на неможливість виключення принципово та in abstracto прийнятності незаконно отриманих доказів [7]. У п. 45 Постанови ЄСПЛ у справі «Смірнов проти Росії від 7 червня 2007 р. суд конкретизував цю правову позицію в частині порушень, допущених під час проведення процесуальних дій, спрямованих на отримання речових доказів. Зокрема, ЄСПЛ вказав, що в цій справі відсутність попередньо виданого судового ордера на обшук і вилучення певною мірою було збалансовано наявною в заявника можливістю оскаржити рішення та дії слідчого в судовому порядку після провадження обшуку. Заявник міг звернутися зі скаргою до суду (що він і зробив), який мав перевірити законність та обгрунтованість постанови на проведення обшуку [15].

Прикладом підходу ЄСПЛ до визнання недопустимими речових доказів, отриманих за обставин, що свідчать про ї явну недопустимість, є Рішення ЄСПЛ у справі «Лісіка проти Хорватії» від 25 лютого 2010 р., у п. п. 50, 57, 58 і 60 якого ЄСПЛ відзначив, що обставини повторно проведеного обшуку транспортного засобу першого заявника BMW, під час якого було отримано єдиний прямий доказ - пластиковий елемент замка, що належить транспортному засобу моделі Golf II (автомобіль такої моделі використовувався під час вчинення нападу на інкасаторський автомобіль, за фактом вчинення якого поліцією здійснювалось розслідування - С. К.), не можуть усунути всі сумніви в його надійності та вплинули на якість доказів у зв'язку з відкриттям автомобіля Golf II працівниками поліції між первинним і повторним обшуками для подальшого обшуку без будь-якого ордера на обшук та поза присутністю заявників або їх законних представників [11]. Аналізуючи наведену справу, науковці вказують: «Суд у ній дійшов висновку про те, що основному доказу не можна вірити. Це радикально новий підхід з огляду на те, що ЄСПЛ досі волів не досліджувати питання про «ненадійні докази» в контексті ст. 6 Конвенції, залишаючи його на розсуд національного судді. Можливо, ця справа залишиться винятком, все-таки їі факти є занадто очевидними, і ненадійність цього доказу дуже кидається в очі» [31, с. 432]. 
На достатність проведених процесуальних дій для формування необхідних речових доказів ЄСПЛ звернув увагу в п. 89 Рішення ЄСПЛ у справі «Кайя проти Туреччини» від 19 лютого 1998 р., у якому стверджується: «Прокурор не спробував перевірити наявність стріляних гільз, які повинні були свідчити про запеклу перестрілку <... йому потрібно було приділити більше уваги збиранню доказів на місці, щоб відтворити події <...> не було перевірено наявність слідів пороху на руках чи одязі вбитого. У будь-якому випадку ці прорахунки повинні вважатись надзвичайно серйозними у зв'язку з тим, що тіло вбитого було пізніше передане жителям села, що зробило неможливим проведення будь-яких додаткових досліджень, у тому числі аналіз куль, які знаходились у тілі. Єдиними речовими доказами, які було взято з місця подій для подальшого розслідування, були зброя та боєприпаси, імовірно використані паном Абдулменафом Кайя. Хоча це важлива слідча дія, не можна не відзначити, що прокурор прийняв рішення, не отримавши результатів балістичної експертизи» [32].

Висновки. Таким чином, у процесі дослідження способів формування доказів, у тому числі й речових, Європейський суд із прав людини використовує статичний підхід, за допомогою якого, як правило, встановлює порушення фундаментальних вимог Конвенції про захист прав людини й основоположних свобод, наслідком яких виступає неможливість використання цих доказів у кримінальному провадженні.

У частині оцінки законності способів збирання речових доказів ЄСПЛ визначає такі питання: 1) належність використовуваних для їх збирання процесуальних дій; 2) дотримання порядку проведення процесуальних дій, спрямованих на збирання речових доказів; 3) достатність проведених процесуальних дій для формування необхідних речових доказів.

Належними процесуальними діями, використовуваними для збирання речових доказів, у розумінні ЄСПЛ виступають такі: 1) огляд житла (справи «Функе проти Франції», «Андре та інші проти Франції»); 2) обшук (справи «Бук проти Німеччини», «Імакаєва проти Росії, «Головань проти України»), у тому числі приміщень (справа «Смірнов проти Росії») і транспортних засобів (справа «Лісіка проти Хорватії); 3) вилучення (справи «Функе проти Франції, «Бук проти Німеччини», «Смірнов проти Росії).

Дотримання порядку проведення процесуальних дій, спрямованих на збирання речових доказів, з позицій ЄСПЛ полягає в такій діяльності: 1) наявності санкції на проведення обшуку й вилучення (справа «Імакаєва проти Росії); 2) чіткому формулюванні постанови про проведення обшуку без надмірно широких (справа «Смірнов проти Росії) і загальних (справа «Андре та інші проти Франції) висловлювань; 3) наявності в ордері на обшук вказівки на підстави для його проведення (справа «Головань проти України»); 4) інформуванні обшукуваного про підстави проведення обшуку: пред’явленні під час обшуку ордеру на обшук та наданні йому інформації про те, що шукають (справа «Імакаєва проти Росії»); 5) здійсненні протоколювання й огляду вилучених речей (справа «Імакаєва проти Росії). 
Під час проведення процесуальних дій, у ході яких вилучаються речові докази, з огляду на практику ЄСПЛ необхідно забезпечити такі моменти:

1) відповідні гарантії, якими виступають: а) достатні гарантії для захисту від зловживань (справа «Функе проти Франції»), у тому числі й адекватні та ефективні заходи захисту від зловживань владою (справа «Кіган проти Сполученого Королівства»); б) гарантії забезпечення охоронюваних законом таємниць, зокрема й адвокатської (справи «Смірнов проти Росії», «Головань проти України»); в) гарантії прав обшукуваного, зокрема його права бути присутнім під час обшуку (справа «Лісіка проти Хорватії»);

2) принцип пропорційності (співмірності) втручання в права громадян меті, яка підлягає досягненню за допомогою відповідних дій (справи «Бук проти Німеччини», «Кіган проти Сполученого Королівства», «Андре та інші проти Франції», «Німітц проти Німеччини», «Функе проти Франції, «Камензінд проти Швейцарії) та їх необхідності в демократичному суспільстві (справа «Смірнов проти Росії» ЄСПЛ).

У більшості справ ЄСПЛ надає ситуативну оцінку дотриманню порядку проведення процесуальних дій, вказуючи на незаконність отримання речових доказів з огляду на обставини конкретної справи й напрацьованої ним практики. Водночас в окремих справах ЄСПЛ однозначно вказує на недопустимість речових доказів і неможливість ї використання, що має місце в таких випадках: 1) отримання речових доказів унаслідок застосування актів насильства, жорстокості або інших форм поводження, які можна характеризувати як тортури, а також погроз іх застосування (наприклад, справи «Яллох проти Німеччини», «Гефген проти Німеччини»); 2) отримання речових доказів за обставин, які свідчать про їх явну недопустимість (наприклад, справа «Лісіка проти Хорватії)).

Достатність проведених процесуальних дій для формування необхідних речових доказів ЄСПЛ визначає з огляду на власне розуміння їх кола, сформованого на основі матеріалів справи, та вказує на процесуальні дії, які підлягали проведенню із цією метою (наприклад, справа «Кайя проти Туреччини»).

\section{Література}

1. Про Стратегію сталого розвитку «Україна - 2020»: Указ Президента України від 12 січня 2015 р. № 5/2015 [Електронний ресурс]. - Режим доступу : http:/ / zakon5.rada.gov.ua/laws/ show $/ 5 / 2015$

2. Про Стратегію реформування судоустрою, судочинства та суміжних правових інститутів на 2015-2020 рр. : Указ Президента України від 20 травня 2015 р. № 276/2015 [Електронний ресурс]. - Режим доступу : http://zakon2.rada.gov.ua/laws/show/276/2015.

3. Про виконання рішень та застосування практики Європейського суду з прав людини : Закон України від 23 лютого 2006 р. № 3477-IV [Електронний ресурс]. - Режим доступу : http:/ / zakon3. rada.gov.ua/laws/show/3477-15.

4. Нор В.Т. Презумпція невинуватості як конституційна засада кримінального судочинства та іï застосування в практиці Європейського Суду з прав людини / В.Т. Нор / / Часопис Національного університету «Острозька академія». Серія «Право». - 2011. - № 1(3). - [Електронний ресурс]. Режим доступу : http://1j.oa.edu.ua/articles/2011/n1/11 nvtzpl.pdf.

5. Рабінович П.М. Європейські стандарти належного доказування у кримінальному судочинстві та стан дотримання їх в Україні / П.М. Рабінович, Б.П. Ратушна / / Право України. - 2014. № 10. - C. 53-63.

6. Тютюнник В.В. Вплив практики Європейського суду з прав людини на розвиток інституту допустимості доказів у кримінальному процесі України / В.В. Тютюнник / / Юрист України. 2013. - № 3(24). - C. 82-87. 
7. Шенк против Швейцарии : Решение Европейского суда по правам человека по делу от 12 июля 1988 г. [Електронний ресурс]. - Режим доступу : http:/ / europeancourt.ru/uploads/ECHR Schenk_v_Switzerland_12_07_1988.pdf.

8. Case of Barbera, Messeguй and Jabardo v. Spain : Judgment of the European Court of Human Rights from December 6, 1988 [Електронний ресурс]. - Режим доступу : http:/ / hudoc.echr.coe.int/ sites / eng/pages / search.aspx?i=001-57429\#\{“itemid”:[“001-57429”]\}.

9. Case of Khan v. the United Kingdom : Judgment of the European Court of Human Rights from May 12, 2000 [Електронний ресурс]. - Режим доступу : http: / / hudoc.echr.coe.int/sites / eng/ pages / search.aspx?i=001-58841\#\{“itemid”:[“001-58841”]\}.

10. Раманаускас проти Литви : Рішення Європейського суду з прав людини в справі від 5 лютого 2008 p. [Електронний ресурс]. - Режим доступу : http: / / www.scourt.gov.ua / clients / vs.nsf / 3adf2d 0e52f68d76c2256c080037bac9/ c48a563ee2b08a54c225758600379986?OpenDocument.

11. Case of Lisica v. Croatia : Judgment of the European Court of Human Rights from February 25, 2010 [Електронний ресурс]. - Режим доступу : http:/ / hudoc.echr.coe.int/sites / eng/pages/search. aspx?i=001-97213\#\{“itemid":[“001-97213”]\}.

12. Быков против Российской Федерации : Постановление Европейского суда по правам человека в деле от 10 марта 2009 г. [Електронний ресурс]. - Режим доступу : http:/ / www.echr.ru/ documents / doc/12068987/12068987-006.htm.

13. Функе против Франции : Решение Европейского суда по правам человека по делу от 25 февраля 1993 г. [Електронний ресурс]. - Режим доступу : http://zakon0.rada.gov.ua/laws/ show /980_154.

14. Бук проти Німеччини : Рішення Європейського суду з прав людини в справі від 28 квітня 2005 р. [Електронний ресурс]. - Режим доступу : http://www.scourt.gov.ua/clients/vs.nsf /0/3b 61 febc6ff9a28ec22574f6005436c3?OpenDocument.

15. Смирнов против России : Постановление Европейского суда по правам человека по делу от 7 июня 2007 г. [Електронний ресурс]. - Режим доступу : http:/ / europeancourt.ru/uploads / ECHR_Smirnov_v_Russia_07_06_2007.pdf.

16. Имакаева против России : Постановление Европейского суда по правам человека по делу от 9 ноября 2006 г. [Електронний ресурс]. - Режим доступу : http://www.srji.org/upload / iblock/29c/20061109_imakayeva_rus.pdf.

17. Андре и другие против Франции : Постановление Европейского суда по правам человека по делу от 24 июля 2008 г. [Електронний ресурс]. - Режим доступу : http://docs.pravo.ru/document/ view / $25924839 / 25702912$.

18. Головань проти України : Рішення Європейського суду з прав людини в справі від 5 липня 2012 p. [Електронний ресурс]. - Режим доступу : http: / /www.golovan.com.ua/fileadmin/Blog/ CASE_OF_GOLOVAN_V_UKRAINE.ukr.pdf.

19. Киган против Соединенного Королевства : Постановление Европейского суда по правам человека по делу от 18 июля 2006 г. [Електронний ресурс]. - Режим доступу : http:/ / docs.pravo. $\mathrm{ru} /$ document/view/19382012/17527393.

20. Макбрайд Дж. Європейська конвенція з прав людини та кримінальний процес / Дж. Макбрайд ; пер. $з$ англ. Д.С. Шкрьоба. - К. : К.І.С., 2010. - 576 с.

21. Нимитц против Германии : Решение Европейского суда по правам человека по делу от 16 декабря 1992 г. [Електронний ресурс]. - Режим доступу : http:/ / europeancourt.ru/uploads ECHR_Niemietz_v_Germany_16_12_1992.pdf.

22. Case of Camenzind v. Switzerland : Judgment of the European Court of Human Rights from December 16, 1997 [Електронний ресурс]. - Режим доступу : http://www.hrcr.org/safrica/ privacy/camenzind_switzerland.html.

23. Олссон против Швеции : Решение Европейского суда по правам человека по делу от 24 марта 1988 г. [Електронний ресурс]. - Режим доступу : http:/ / europeancourt.ru/uploads/ECHR Olsson_v_Sweden_N_1_28_03_1988.pdf.

24. Яллох против Германии : Решение Европейского суда по правам человека по делу от 11 июля 2006 г. [Електронний ресурс]. - Режим доступу : http: / / precedent.in.ua/index.php?id=1189170435.

25. Харутюнян против Армении : Постановление Европейского суда по правам человека по делу от 28 июня 2007 г. [Електронний ресурс]. - Режим доступу : http://docs.pravo.ru/document/ view / $19380735 / 17524978$.

26. Гефген против Германии : Постановление Европейского суда по правам человека по делу от 30 июня 2008 г. [Електронний ресурс]. - Режим доступу : http:/ / precedent.in.ua/index. php?id=1350301588.

27. Алексахін проти України : Рішення Європейського суду з прав людини в справі від 19 липня 2012 р. [Електронний ресурс]. - Режим доступу : http: / / zakon4.rada.gov.ua/laws/show/974_925. 
28. Гечмен против Турции : Постановление Европейского суда по правам человека по делу от 17 октября 2006 г. [Електронний ресурс]. - Режим доступу : http://docs.pravo.ru/document/ view/19381742/17526822.

29. Левинца против Молдовы : Постановление Европейского суда по правам человека по делу от 16 декабря 2008 г. [Електронний ресурс]. - Режим доступу : http://pytkam.net/v-pomoschpostradvshemu.reshenija-evropeyskogo-suda-po-pravam-cheloveka/0000004.

30. Европейские стандарты права на справедливое судебное разбирательство и российская практика / под общ. ред. А.В. Деменевой. - Екатеринбург : Изд-во Уральского ун-та, 2004. - 240 с.

31. Стандарты справедливого правосудия (международные и национальные практики) / под ред. Т.Г. Морщаковой. - М. : Мысль, 2012. - 584 с.

32. Кайя против Турции : Решение Европейского суда по правам человека по делу от 19 февраля 1998 г. [Електронний ресурс]. - Режим доступу : http:/ / europeancourt.ru/uploads/ECHR_ Kaya_v_Turkey_19_02_1998.pdf.

\section{А н о т а ці я}

Ковальчук С. О. Європейські правові стандарти формування в ході кримінального провадження допустимих речових доказів. - Стаття.

Статтю присвячено дослідженню напрацьованих Європейським судом із прав людини правових стандартів формування допустимих речових доказів у кримінальному провадженні. 3 огляду на статичний підхід Європейського суду з прав людини до оцінки законності способів збирання речових доказів характеризуються його правові позиції щодо кола використовуваних для їх збирання процесуальних дій, дотримання порядку проведення цих дій та їх достатності для формування необхідних речових доказів.

Ключові слова: європейські правові стандарти, кримінальне провадження, речові докази, допустимі докази, формування доказів.

\section{Анн о т а ци я}

Ковальчук C. A. Европейские правовые стандарты формирования в ходе уголовного производства допустимых вещественных доказательств. - Статья.

Статья посвящена исследованию наработанных Европейским судом по правам человека правовых стандартов формирования допустимых вещественных доказательств в уголовном производстве. С учетом статического подхода Европейского суда по правам человека к оценке законности способов собирания вещественных доказательств характеризуются его правовые позиции относительно круга используемых для их собирания процессуальных действий, соблюдения порядка проведения этих действий и их достаточности для формирования необходимых вещественных доказательств.

Ключевые слова: европейские правовые стандарты, уголовное производство, вещественные доказательства, допустимые доказательства, формирование доказательств.

\section{S u m m a r y}

Kovalchuk S. O. The European legal standards for formation of admissible material evidences in criminal proceedings. - Article.

The article is dedicated to the consideration of the European legal standards for formation of admissible material evidences in criminal proceedings, established by the European Court of Human Rights. Considering the static approach of the European Court of Human Rights to assessing the legality of the collection methods of material evidences, its legal positions relatively range of procedural actions, used for their collection, compliance of the order of these actions and their adequacy for the formation of the necessary material evidences, characterized.

Key words: European legal standards, criminal proceedings, material evidence, admissible evidence, formation of evidences. 